\title{
The effects of storage temperature on the growth of Vibrio parahaemolyticus and organoleptic properties in oysters
}

\section{Meshack Fon Mudoh, Salina Parveen*, Jurgen Schwarz, Tom Rippen and Anish Chaudhuri}

Food Science and Technology Program, Department of Agriculture, Food and Resource Sciences, University of Maryland Eastern Shore, Princess Anne, MD, USA

Edited by:

Khwaja M. Sultanul Aziz, Bangladesh

Academy of Sciences, Bangladesh

\section{Reviewed by:}

Nur A. Hasan, University of Maryland College Park, USA

Sangita Ahmed, University of Dhaka, Bangladesh

\section{*Correspondence:}

Salina Parveen, University of Maryland Eastern Shore, Center for Food Science and Technology, 1 Backbone Road, Princess Anne, MD 21853, USA

e-mail:sparveen@umes.edu
During harvesting and storage, microbial pathogens and natural spoilage flora may grow, negatively affecting the composition and texture of oysters and posing a potential health threat to susceptible consumers. A solution to these problems would mitigate associated damaging effects on the seafood industry. The purpose of this study was to investigate the effects of storage temperature on growth of vibrios as well as other microbial, sensory, and textural characteristics of post-harvest shellstock Eastern oysters (Crassostrea virginica). Oysters harvested from the Chesapeake Bay, Maryland, during summer months (June, July, and August, 2010) were subjected to three storage temperatures $\left(5,10\right.$, and $\left.20^{\circ} \mathrm{C}\right)$ over a 10-day period. At selected time intervals $(0,1,3,7$, and 10 days), two separate samples of six oysters each were homogenated and analyzed for $\mathrm{pH}$, halophilic plate counts (HPC), total vibrios, and Vibrio parahaemolyticus (Vp). Oyster meats shucked after storage were also organoleptically evaluated (acceptability, appearance, and odor). Texture analysis was performed using a texture analyzer on meats shucked from oysters held under the same conditions. The $\mathrm{pH}$ of the oyster homogenates showed no consistent pattern with storage time and temperature. The HPC (4.5-9.4 log CFU/g) were highest on day 7 at $20^{\circ} \mathrm{C}$ while olfactory acceptance reduced with time and increasing storage temperatures. The $V p$ counts increased over time from 3.5 to $7.5 \mathrm{log}$ MPN/g by day 10. Loss of freshness as judged by appearance and odor was significant over time $(p<0.05)$. Toughness of oysters increased with storage time at 5 and $10^{\circ} \mathrm{C}$ from days 1 to 3 but was inconsistent after day 7. The results indicate that the length of storage and temperature had a significant effect on bacterial counts and olfactory acceptance of oysters but had an inconsistent effect on texture.

Keywords: Vibrio parahaemolyticus, halophilic plate count, oysters, sensory, texture

\section{INTRODUCTION}

The Eastern oyster (Crassostrea virginica), commonly found in the intertidal zones of the eastern United States, has been traditionally harvested as a food source for thousands of years (1). Annual harvests of this species nationally were around 184.4 million pounds from 2005 to 2012 (2). Raw oysters are a natural source of minerals like calcium, iron, selenium, and zinc as well as high amounts of vitamin B12 and omega 3 fatty acids that improve neurological and cardiovascular health (3). Unfortunately, there is a high health risk for individuals who eat raw oysters because their natural flora may harbor human pathogens (4-6). Among the Gram-negative rods, Vibrio parahaemolyticus (Vp) is economically important because of its virulence. This halophilic bacterium (Family: Vibrionaceae) is commonly abundant in the estuarine waters worldwide and causes gastroenteritis in humans $(7,8)$. Human transmission of this pathogen is mainly through the consumption of raw, poorly cooked, or mishandled seafood including oysters. In addition to gastroenteritis with occasional bloody diarrhea, primary septicemia can occur in individuals with underlying chronic illness $(8,9)$. A number of Vp outbreaks associated with oyster consumption have been reported in the US and other countries in the past several years. Reports from the past decade indicate that $V p$ has accounted for approximately two-thirds of seafood borne infections in the US. These reports further indicated that $V p$ numbers in oysters and water increase with warmer temperatures $(5,9,10)$. Several investigators $(5,6)$ confirmed that $V p$ growth was affected more by temperature than by salinity. The same authors also reported that oysters contained 233 times more $V p$ than the ambient water. Optimum growth of this pathogen occurs between 30 and $35^{\circ} \mathrm{C}$ with an upper limit of $45.3^{\circ} \mathrm{C}$ and in a range of $2-4 \%$ sodium chloride. Although $V p$ can grow over a broad $\mathrm{pH}$ range $(4.8-11.0)$, the optimal range is $\mathrm{pH} 7.6-8.6(8,11)$.

In order to limit the growth of $V p$ in oysters, the National Shellfish Sanitation Program (12) established time-temperature regulations that restrict maximum exposure time of oysters to ambient temperatures. The regulation requires harvested oysters for raw consumption to be cooled to $10^{\circ} \mathrm{C}\left(50^{\circ} \mathrm{F}\right)$ or below within $10 \mathrm{~h}$ of harvest or less. A risk assessment conducted by the US Food and Drug Administration (13) found levels of VP to be substantially influenced by post-harvest handling methods. The assessment pointed out that temperature abuse of oysters by improper refrigeration induces higher growth rates of $V p$. This bacterium is also reported to multiply rapidly with a short 
generation time in both broth and seafood between 18 and $40^{\circ} \mathrm{C}$ $(8,11)$. Other research findings suggest that refrigerated storage should be considered a critical control point (CCP) in hazard analysis and critical control points (HACCP) plans for raw shellstock (4).

Temperature abuse may lead to pathogen growth as well as spoilage. It has been reported that the breakdown of glycogen, a high energy storage molecule in the oyster tissues, influences spoilage patterns of shucked oyster meats through fermentation. The resulting lactic acid accumulation and drop in $\mathrm{pH}$ favor the growth of Lactobacilli, Streptococci, and yeasts (14, 15). These changes may affect the sensory characteristics of oysters. Sensory evaluation of a food item sheds light on its consumer acceptability. Research indicates that when homogenated oyster meat and liquor $\mathrm{pH}$ drop into the range of 5.6-6.1 sensory scores decline from good to stale, or stale to sour or putrid for $\mathrm{pH}$ between 4.9 and 5.3, and then to an "advanced decomposition" stage for $\mathrm{pH} \leq 5.0$. This relationship of shucked oyster meat and liquor has been established as a basis for evaluating its wholesomeness (14). Lorca et al. (4) compared oyster bacterial counts with sensory perception. Olfactory acceptability and storage time were negatively correlated, and the former was below $40 \%$ when Vibrio vulnificus $(V v)$ growth was at its highest. These researchers only measured the olfactory acceptability of shellstock oysters.

Complimenting sensory information with instrumental analyses can improve the accuracy of the observations (16). Texture is an important characteristic of food quality especially in aquatic foods (17) and can provide valuable information about food storage and handling conditions. There is inadequate sciencebased information about the effects of storage temperature on the growth of $V p$, and corresponding physical and sensory properties of shellstock (live) oysters that is relevant to the shellfish industry and consumers. The objective of this study was to address these data gaps.

\section{MATERIALS AND METHODS \\ OYSTER SAMPLES}

Oyster samples (C. virginica) were collected from the Chesapeake Bay, MD, USA, during the summer months (June-August 2010). The oyster samples were then placed in pre-labeled clean plastic bags, transferred to an insulated chest, and bubble wrapped. Ice bags were placed on the wrap to prevent direct contact of samples with ice. The temperature was monitored during shipping to verify that it was $<10^{\circ} \mathrm{C}$, which is the minimum temperature for growth of $V p$ (11). The samples were transported to the laboratory for subsequent analyses. In addition, harvest water temperature and salinity were measured in the upper $0.5 \mathrm{~m}$ of the surface water using a dissolved oxygen-conductivity meter (Model 85, Yellow Springs Instrument Co., Yellow Springs, OH, USA). All microbiological assays were initiated within $4-6 \mathrm{~h}$ of sample collection (5). For this study, sets of 50 oysters were stored at 5, 10, and $20^{\circ} \mathrm{C}$ to mimic typical conditions of oyster handling, where $5^{\circ} \mathrm{C}$ is the desired refrigeration temperature, $10^{\circ} \mathrm{C}$ the abusive refrigeration temperature, and $20^{\circ} \mathrm{C}$ reflecting ambient temperatures often occurring during oyster harvest. At selected time intervals $(0,1$, 3,7 , and 10 days), two separate subsets of six oysters each were analyzed for halophilic plate counts (HPC), total vibrios, and $V p$ counts. All analyses were performed on viable oysters. The samples for microbiological analyses were removed, and the $\mathrm{pH}$ of the remaining oyster homogenates was determined for each sample using a calibrated pHTESTR $^{\mathrm{TM}}$ (Oakton Instruments, IL, USA).

All experiments were carried out in replicates of three, and for each replication, sample analyses were performed in duplicates.

\section{MICROBIAL ANALYSES}

At each selected time interval, two sub-samples (six oysters/sample) were scrubbed, rinsed, shucked, and then diluted 1:1 $(\mathrm{w} / \mathrm{w})$ with sterile phosphate-buffered saline [PBS, $76.5 \mathrm{~g} \mathrm{NaCl}$, $0.724 \mathrm{~g}$ of anhydrous $\mathrm{Na}_{2} \mathrm{HPO}_{4}, 0.21 \mathrm{~g}$ of $\mathrm{KH}_{2} \mathrm{PO} 4 / \mathrm{l}, \mathrm{pH} 7.4$ (Sigma $^{\circledR}$, St. Louis, MO, USA)]. The oyster homogenates were blended on high speed for $90 \mathrm{~s}$ in a sterile Warring ${ }^{\circledR}$ blender. A 1:10 dilution $(\mathrm{w} / \mathrm{w})$ of oyster homogenate was obtained by mixing $20 \mathrm{~g}$ of homogenate and $80 \mathrm{~g}$ of PBS. Serial dilutions were then prepared in PBS ( $\mathrm{v} / \mathrm{v}$ basis). One hundred microliters and $1 \mathrm{ml}$ samples from each dilution were inoculated into trypticase soy agar (TSA) $+2.5 \% \mathrm{NaCl}$ plates for HPC (Difco Laboratories ${ }^{\circledR}$, Detroit, MI, USA) and 10-ml aliquots of alkaline peptone water $(1 \times \mathrm{APW}$, at $\mathrm{pH} 8.5)$ three-tube most probable number (MPN) series, respectively. TSA plates were read for HPC after $48 \mathrm{~h}$ of incubation at $35^{\circ} \mathrm{C}$. For MPN, after $24 \mathrm{~h}$ of incubation, one loop of inoculate from the top $1 \mathrm{~cm}$ of fluid of each APW tube (5) was streaked onto thiosulfate citrate bile salts (TCBS) agar (Difco ${ }^{\circledR}$ ) plates and incubated for $24 \mathrm{~h}$ at $35^{\circ} \mathrm{C}$. TCBS plates were checked for any growth to indicate total Vibrio counts. The growth data were combined and total Vibrio MPN/g was calculated using a threetube MPN table $(4,18)$. After $24 \mathrm{~h}$ incubation, all turbid APW tubes were analyzed by q-PCR for the detection of $V p$. From each turbid tube, $200 \mu \mathrm{l}$ of each oyster enrichment broth was boiled for $10 \mathrm{~min}$ and then plunged into ice. The cooled aliquots were spun at $10,000 \times g$ for 2 min to pellet cellular debris and a $2-\mu 1$ portion of the supernatant was used as template in the q-PCR assay to detect the presence of the th gene. All primer and probe sequences, reaction conditions, cycling, and analysis parameters were used as previously described (19).

\section{SENSORY EVALUATION}

The sensory evaluation (appearance and odor) was performed with the help of 25 semi-trained panelists from the University of Maryland Eastern Shore campus, Princess Anne, MD, USA (males11; females-14; age group: 20-60) using $15 \mathrm{~cm}$ semi-structured category scale for freshness. All panelists were trained to mark horizontally across the scale lines to indicate their judgment of the oyster. The left hash mark on each category scale indicated "very fresh" while the right hash mark indicated "not fresh." During the evaluation, every panelist was provided with three shucked oysters with its liquor representing the three different storage temperatures at each selected time interval. Oyster samples were coded with three-digit random numbers and presented to panelists in random balanced order under fluorescent light at room temperature (4). The panelists were asked to evaluate the samples for degree of freshness by appearance and odor on the $15-\mathrm{cm}$ scale. Similar scales are used to quantify specific attributes in a food item (20). Panelists were also asked to indicate yes or no if they would eat each oyster presented. 


\section{TEXTURE ANALYSES}

Texture was analyzed by measuring the resistance to shear using a TA-XT2 texture analyzer (Stable Micro System, Godalming, England) with a $5-\mathrm{kN}$ load cell. The shucked oyster meat was placed on the instrument platform under a knife blade $(3 \mathrm{~mm}$ thick with a $45^{\circ}$ chisel end), compressed, and sheared to measure the force of penetration (resistance to shear). Great care was taken to position the oyster samples so that the blade contacted the meat at its thickest point. The crosshead speed was set at $1 \mathrm{~mm} / \mathrm{s}$, the distance set for the blade to stop within $1 \mathrm{~mm}$ of the platform after which it returned automatically to the start position, and the test was triggered by a $5-\mathrm{N}$ contact force.

The force-time graphs were recorded and analyzed using the Texture Expert for Windows (version 5.0.9.0, Stable Micro Systems, Ltd., UK.). The peak force was expressed as maximum resistance to shear $(\mathrm{N})$ and the area under the curve as total work $(\mathrm{N} \times \mathrm{mm})$ and is a measure of toughness of the oysters (17).

\section{STATISTICAL ANALYSES}

Before analyses, geometric means of all data were normalized using log or square root transformation methods (as appropriate) to reduce numerical variability in the dataset. A two-way between groups, analysis of variance (ANOVA) was used to evaluate the role of storage temperatures and time (days) on microbiological counts in oyster samples $(p<0.05)$. Pearson correlation was used to evaluate the data from sensory experiments. Panelist marks on the scales were translated as percent of full scale (0-100, with 100 indicating the highest level of freshness) and analyzed using one-way ANOVA, Tukey HSD all-pair-wise comparisons test and Pearson correlation $(p<0.05)$. All statistical analyses were done using Statistica ${ }^{\circledR}$ (StatSoft, Inc., OK, USA. Statistica data analysis software system, version 9.0. www.statsoft.com).

\section{RESULTS}

\section{OYSTER QUALITY AND pH}

The $\mathrm{pH}$ values of oyster meat and liquor stored at 5,10 , and $20^{\circ} \mathrm{C}$ for 10 days are shown in Table 1. The $\mathrm{pH}$ appeared to drop from days 0 through 3 for oysters stored at 5 and $10^{\circ} \mathrm{C}$ but then increased. These apparent changes in $\mathrm{pH}$ were not statistically significant $(p>0.05)$.

\section{HALOPHILIC PLATE COUNTS}

Halophilic plate counts of oysters were highest on day 7 at $20^{\circ} \mathrm{C}$ and on day 10 at 5 and $10^{\circ} \mathrm{C}$ during storage, with a log range of about 4.5-9.4 $\log$ CFU/g (Figure 1). The HPC increased significantly as time and temperature increased $(p<0.05)$.

\section{TOTAL VIBRIOS}

Total vibrios increased over time at $20^{\circ} \mathrm{C}$ (Figure 2). The highest total Vibrio count was observed on day 10 at $20^{\circ} \mathrm{C}$ storage, with about 3.4-7.5 $\log$ CFU/g difference from day 0. There was no statistical difference $(p>0.05)$ in the growth of total Vibrios at 5 and $10^{\circ} \mathrm{C}$ in this study. The effect of time and temperature on Vibrio counts was statistically significant at $20^{\circ} \mathrm{C}(p<0.05)$.

\section{VIBRIO PARAHAEMOLYTICUS}

On day 0 , the level of $V p$ was $3.5 \log \mathrm{CFU} / \mathrm{g}$ in oyster samples (Figure 3). Growth trends for $V p$ were similar as for total vibrios.
Table 1 | Changes in $\mathrm{pH}$ values of oysters during a 10-day storage period.

\begin{tabular}{ccc}
\hline Storage time $(\boldsymbol{d})$ & Storage temperature $\left({ }^{\circ} \mathbf{C}\right)$ & Average $\mathbf{p H} \pm \mathbf{S D}$ \\
\hline 0 & - & $6.55 \pm 0.19$ \\
1 & 5 & $6.42 \pm 0.02$ \\
& 10 & $6.44 \pm 0.01$ \\
& 20 & $6.43 \pm 0.03$ \\
3 & 5 & $6.43 \pm 0.05$ \\
& 10 & $6.42 \pm 0.01$ \\
& 20 & $6.46 \pm 0.08$ \\
7 & 5 & $6.46 \pm 0.03$ \\
& 10 & $6.45 \pm 0.02$ \\
& 20 & $6.36 \pm 0.16$ \\
10 & 5 & $6.57 \pm 0.03$ \\
& 10 & $6.62 \pm 0.15$ \\
& 20 & $6.08^{a}$ \\
\hline
\end{tabular}

${ }^{a}$ There was only one value for this set of data as the other oysters perished.

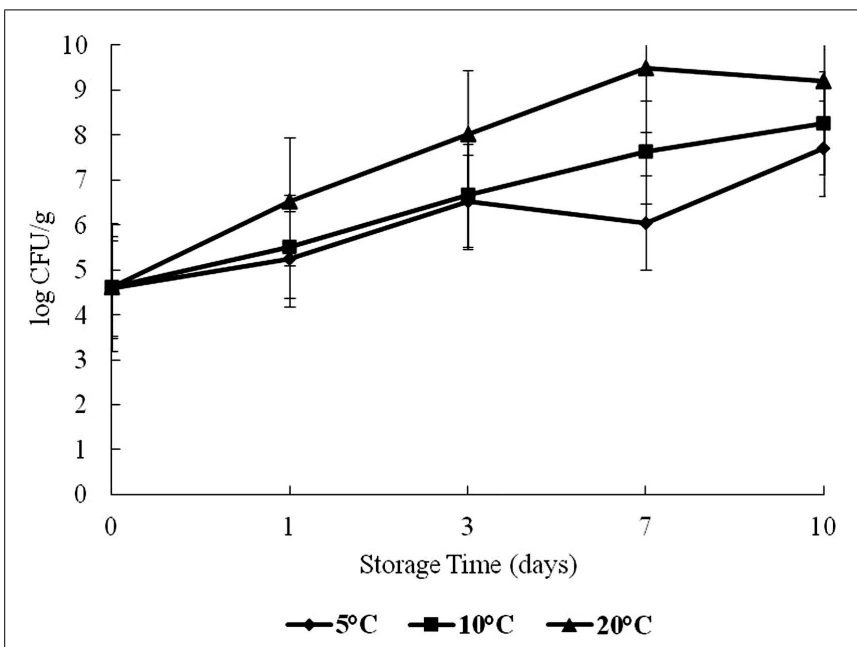

FIGURE 1 | Halophilic plate count (HPC) of oysters during a 10-day storage period at 5,10 , and $20^{\circ} \mathrm{C}$.

$V p$ levels increased significantly $(p<0.05)$ over time with storage temperatures (Figure 3 ). This study observed a dramatic increase after day 3 at $20^{\circ} \mathrm{C}$. The highest level of $V p$ counts was observed on day 10 at $20^{\circ} \mathrm{C}$ storage, with about a 3-log increase from day 0 . No increase was observed in $V p$ counts at 5 and $10^{\circ} \mathrm{C}$.

\section{ACCEPTABILITY TO CONSUME OYSTERS}

Figure 4 shows the result of panelists' organoleptic response to samples during the 10 -day storage period. At day 0 , approximately $90 \%$ of panelists indicated "yes" to their willingness to consume the oysters. From days 1 to 10, the percentage of panelists willing to consume the oysters dropped steadily.

At 5 and $10^{\circ} \mathrm{C}$ storage temperatures, the acceptance dropped to about $60 \%$ of panelists who were willing to consume the oysters on day 10 . At $20^{\circ} \mathrm{C}$, sensory acceptance dropped dramatically throughout the study to about $30 \%$. In this study, all 


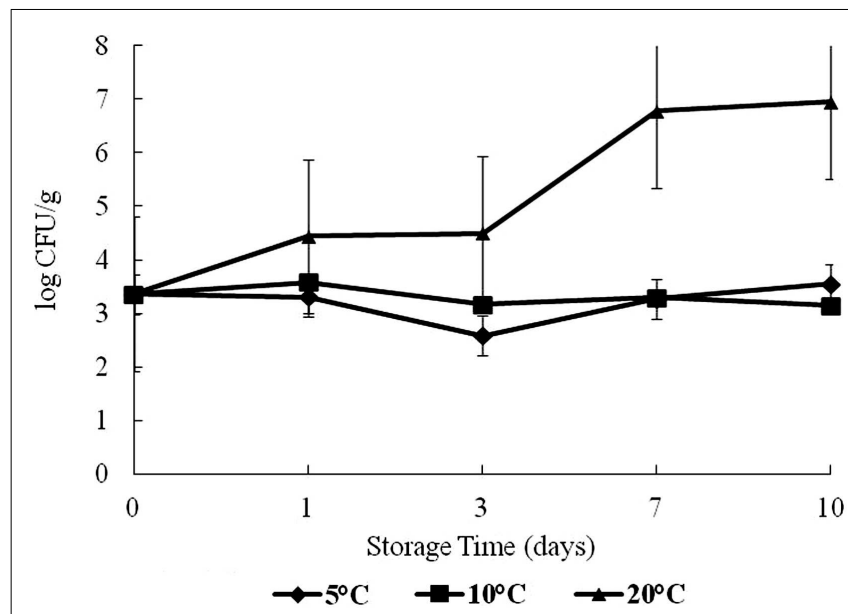

FIGURE 2 | Levels of total vibrios during 10 days of storage at 5, 10, and $20^{\circ} \mathrm{C}$

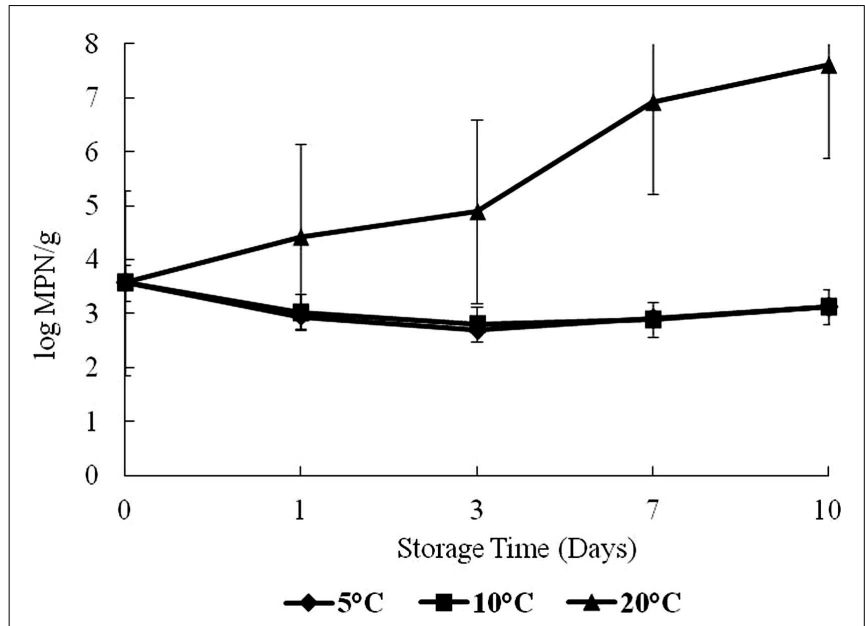

FIGURE 3 | Levels of Vibrio parahaemolyticus during 10 days of storage at 5,10 , and $20^{\circ} \mathrm{C}$

microbiological variables showed a positive correlation with storage time, and as storage time and temperature increased, the olfactory acceptability of oysters decreased.

\section{RESPONSE OF PANELISTS TO VISUAL APPEARANCE AND ODOR OF OYSTERS}

The data for visual appearance and odor were strongly correlated $(p<0.05)$ indicating that as the temperature increased, both appearance and odor deteriorated. Odor and appearance freshness scores declined significantly from days 7 to 10 and at 10 and $20^{\circ} \mathrm{C}$ $(p<0.05)$ (Figures 5 and 6). A separate pair-wise comparison test for odor and time with temperature increase, showed a significant decrease in fresh odor only from days 7 to $10(p<0.05)$. In this study, HPC significantly increased with temperature and time, and the decline in freshness judged by odor and appearance followed the same trend.

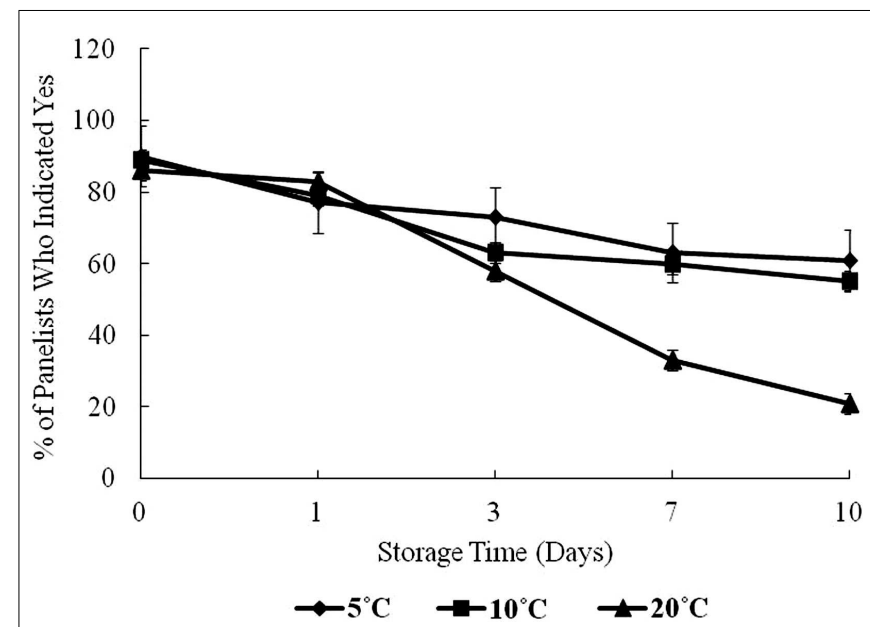

FIGURE 4 | Sensory evaluation of oysters under controlled conditions over a 10-day storage period at 5,10 , and $20^{\circ} \mathrm{C}$, percent of panelists indicating yes, they would consume the oyster.

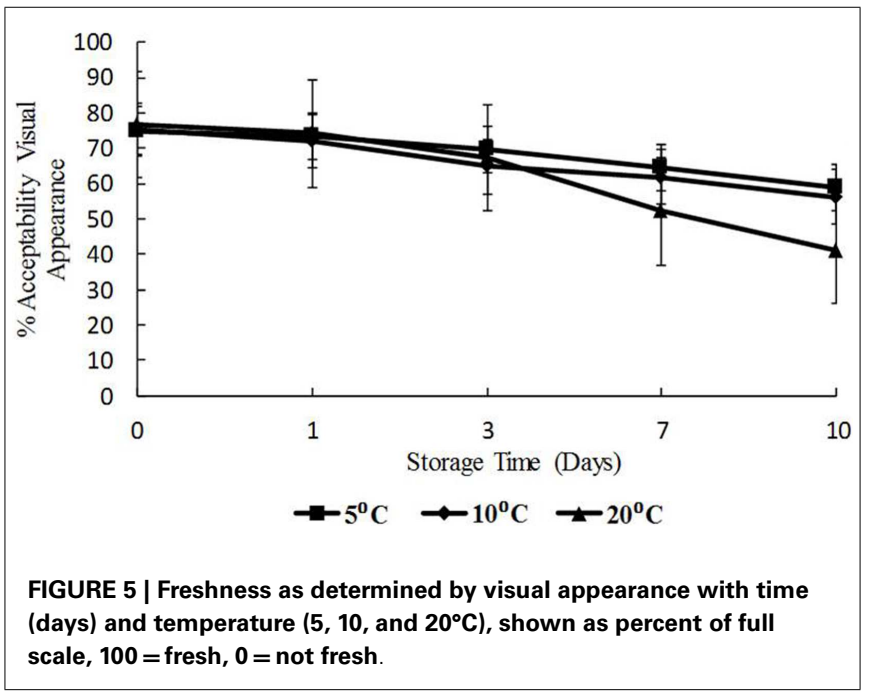

TEXTURAL ANALYSES

The results of texture analysis of oysters stored for 10 days under the various temperature conditions $\left(5,10\right.$, and $\left.20^{\circ} \mathrm{C}\right)$ are shown in Figure 7. The peak force increased for all three storage temperatures from days 0 to 3 was not significant. In contrast, the increases in peak force up to day 3 for the 10 and $20^{\circ} \mathrm{C}$ treatments and the increase for the $5^{\circ} \mathrm{C}$ treatment between days 0 and 1 were significant $(p<0.05)$. The $10^{\circ} \mathrm{C}$ treatment showed a steady decrease in peak force from days 3 to 10 , while the $20^{\circ} \mathrm{C}$ treatment decreased to day 7 . The apparent peak force increase on day 10 at $20^{\circ} \mathrm{C}$ was not significant. At $5^{\circ} \mathrm{C}$ the peak force decreased to day 7 , after which an apparent slight but insignificant increase was observed $(p>0.05)$. The total work defined by the area under the shear resistance curve is shown in Figure 8. The increase of peak force was observed at day 3 with a subsequent decrease at day 7. 


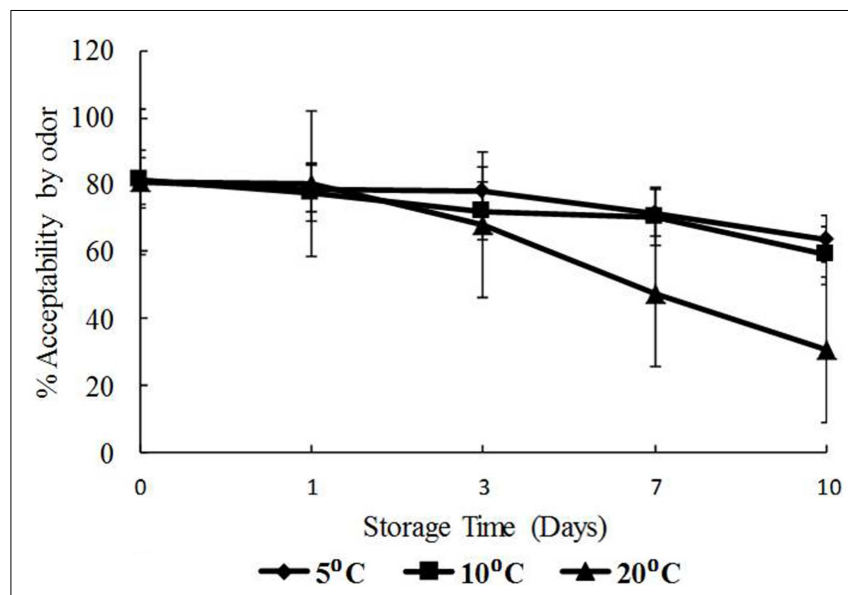

FIGURE 6 | Freshness as determined by odor with time (days) and temperature $\left(5,10\right.$, and $\left.20^{\circ} \mathrm{C}\right)$, shown as percent of full scale, $100=$ fresh, $0=$ not fresh

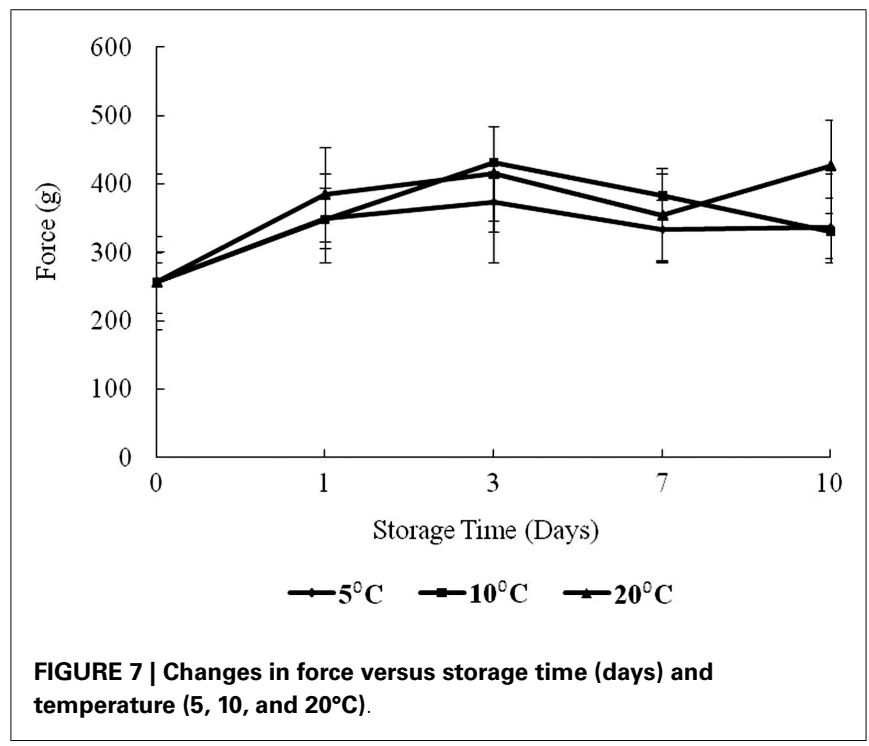

\section{DISCUSSION}

The present study is the most comprehensive and first report to date on the effects of storage temperature on the growth of $V p$, and physical and sensory properties of live oysters. Oysters were harvested from the Chesapeake Bay during the warmer months and stored over a range of temperatures to be representative of industry and consumer practices.

It has been reported that as the $\mathrm{pH}$ of stored shucked oyster meats drop to five or below, the meat is considered spoiled and unfit for consumption (14). The results on $\mathrm{pH}$ variations in this study are consistent with the works of Lorca et al. (4) as well as Hunter and Linden (14). Lorca et al. (4) observed that the $\mathrm{pH}$ of the shellstock samples never fell below an average of 5.9, and in this study, the lowest $\mathrm{pH}$ was 6.08 . These were live marine organisms held out of water and their physiology likely reflected their starved condition. Glycogen would be utilized quickly and not readily restored. Unlike shucked oyster meats, the absence of a continued

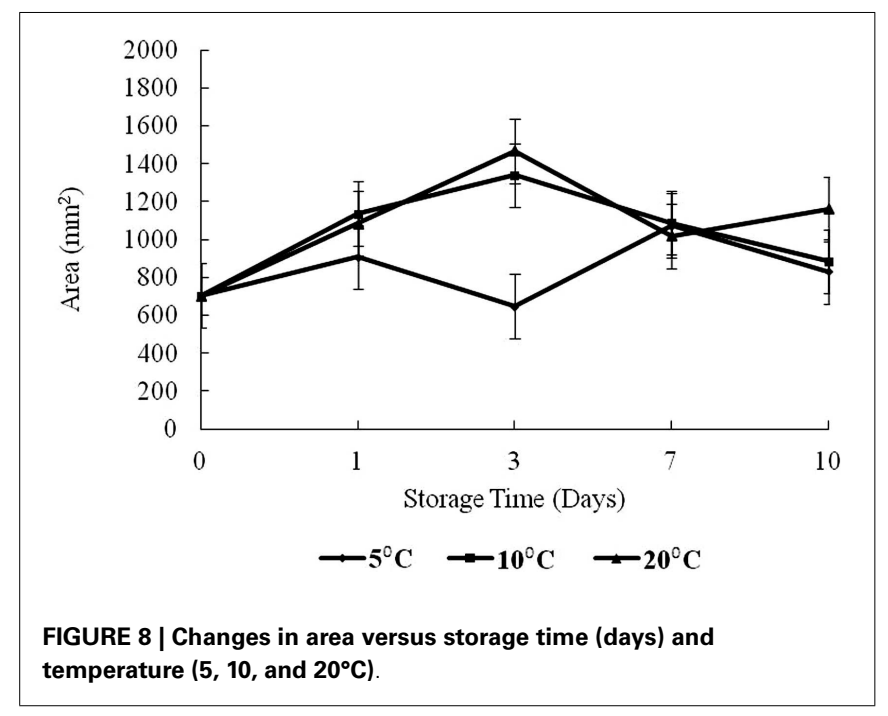

downward trend in $\mathrm{pH}$ during the shellstock oyster storage might be attributed to the near lack of fermentative spoilage in shellstock. From this study, $\mathrm{pH}$ does not appear to be a useful indicator of bacterial growth in live oysters considering the observed growth of $V p$.

The combined effect of time and storage temperature on HPC was statistically significant $(p<0.05)$. Despite the general increase in HPC, there was an observed drop from days 3 to 7 for the $5^{\circ} \mathrm{C}$ treatment which was statistically insignificant $(p>0.05)$. The $20^{\circ} \mathrm{C}$ treatment also showed a decrease from days 7 to 10 . Bacteria competing for nutrients may have caused this observed drop. Perhaps, those cells that survived the competition regained vigor to grow. The growth pattern of HPC in this study finds support from studies conducted by Hood et al. (21) and Lorca et al. (4). These authors observed a similar effect in both shellstock and shucked oysters stored at selected temperatures $\left(2,8,20\right.$, and $\left.30^{\circ} \mathrm{C}\right)$.

Total Vibrio counts remained at approximately $3.3 \mathrm{log} \mathrm{CFU} / \mathrm{g}$ or below at 5 and $10^{\circ} \mathrm{C}$ indicating that low temperatures can suppress total Vibrio growth. This study corroborates the findings of Cook and Ruple (15) as well as Lorca et al. (4). They had reported similar total Vibrio results with post-harvest shellstock oysters stored at 7 , $13,21,22$, and $30^{\circ} \mathrm{C}$ for a 10 -day period in oysters.

In this study, average harvest water temperature and salinity were $22.8 \pm 2.71^{\circ} \mathrm{C}$ and $21.47 \pm 5.11 \mathrm{ppt}$, respectively. These parameters are consistent with the results of a previous study in the Chesapeake Bay (5). These researchers attributed the highest levels of $V p$ to warm water temperatures and relatively low salinities. The detection of $V p$ agrees with research findings that have reported higher $V p$ levels in oysters during the warmer months $(5,6)$.

Vibrio parahaemolyticus levels over time increased with storage temperatures. Lorca et al. (4) reported similar results for $V v$ in shellstock oysters stored at 7,13 , and $21^{\circ} \mathrm{C}$ for a 10 -day period. Cook and Ruple (15) reported a similar rise in Vibrio levels in postharvest shellstock oysters stored at $22-30^{\circ} \mathrm{C}$. Recently, Parveen et al. (11) reported that $V p$ multiplied rapidly when oysters were stored at $15^{\circ} \mathrm{C}$ or above, with no growth at 5 and $10^{\circ} \mathrm{C}$. The results of this study suggest that storage of oysters at or below $10^{\circ} \mathrm{C}$ is effective for preventing Vp growth in shellstock oysters. 
In this study, the "freshness score" by panelists gradually decreased during storage at different temperatures. Relating the bacterial growth to the response of the panelists showed a high level of agreement. Willingness to consume oysters was inversely related to the rise in HPC and Vp over time, especially at the highest temperature, $20^{\circ} \mathrm{C}$. These results are consistent with the results of Cao et al. (22) in a study of Pacific oysters (Crassostrea gigas) at different storage temperatures. It was also observed that appearance and odor of oysters were negatively correlated to bacterial counts, storage time, and elevated temperatures. However, these results also show that simple olfactory analysis of raw shellstock may not be adequate to prevent oyster-associated Vp illness. The authors suggest that extended high temperature storage $\left(20^{\circ} \mathrm{C}\right)$ could pose a health threat to a minority of consumers willing to consume them (30\% of panelists willing to consume on day 7 ).

The $\mathrm{pH}$ of the oysters in this study never fell below 6.08, indicating little loss of quality resulting from the growth of fermentative bacteria. As previously discussed, HPC growth was higher than $V p$ by a minimum of 2 logs at all storage conditions. It was also noted that at $20^{\circ} \mathrm{C}$, the levels of $V p$ were significantly higher than at lower temperatures (with an increased growth of about $3.8 \mathrm{MPN} / \mathrm{g}$ ). Storage of shellstock at elevated temperatures and time stimulated $V p$ growth without altering the chemical quality of the oysters (as indicated by $\mathrm{pH}$ ). It should be understood that as both $\mathrm{pH}$ and olfactory acceptability of oysters stored at elevated temperatures fell within the accepted range, there was a possibility of concurrent elevated levels of $V p$ that could present a potential undetected health threat to consumers.

Peak force is a measure of hardness of a product tested while the area or total work represents toughness (17). Dobraszcyk and Vincent (23) define the area as the energy required to fully compress the tissue up to the point of failure and reflects the toughness or extensibility of the tissue. Aussanasuwannakul et al. (17) did not observe a change in peak force of refrigerated salmon raw filets (for 3 and 7 days). Subsequent freezing of the filets for 30 days resulted in an apparent reduction in peak force, though insignificant. The authors also observed a slight increase in total work from 3 to 7 days of refrigerated storage, but this change was also insignificant. By contrast in broiler breasts, Lee et al. (24) determined that tenderness (measured by Meullenet-Owens razor) shear force and energy decreased during long-term frozen storage (4 months) due to muscle shrinkage by dehydration. The increase of peak force observed at day 3 in the present study might have been caused by an initial loss of moisture. The decrease at day 7 could have been caused by catabolic processes or proteolytic degradation of myofibrillar structures and connective tissue networks which reduce shear resistance as discussed by Ashie and Simpson (25). It is noteworthy to mention that at the time of writing this manuscript, the authors could not find any comparable textural study on oysters in existing databases.

It has to be noted that the oysters used in this study were alive, although they were not stored in water. In living tissue, there is a constant state of equilibrium between the plasma protein, the amino acids of the blood, and the tissue proteins (26). In this study, it seems that constituent equilibrium could not be maintained in the live oysters during storage, producing the observed changes in peak force. However, further studies on the chemistry of proteins, native enzymes, and moisture migration at different storage temperatures over time would improve understanding of texture changes in shellstock oysters.

The area under the force versus time curve represents the energy required to fully compress the tissue up to the point of failure and reflects the toughness or extensibility of the tissue (23). In this study, the area was observed to increase to day 3 for 10 and $20^{\circ} \mathrm{C}$ treatments $(p<0.05)$. The area for $10^{\circ} \mathrm{C}$ oysters continued with a decrease to day 10 while for the $20^{\circ} \mathrm{C}$ treatment, there was also an observed decrease from days 3 to 7 followed by an increase in area on day 10 . For $5^{\circ} \mathrm{C}$, the total work measured did not show any obvious trend, increasing to day 1 , and then decreasing to day 3 followed by an increase to day 7 with virtually no change to day 10 . The initial increase seen at all temperatures is likely the result of dehydration. The differences in total resistance from days 3 to 10 could reflect the enzymatic degradation of proteins. These oysters were live animals and physiologically active, except possibly near the end of the storage period at $20^{\circ} \mathrm{C}$.

In conclusion, all microbiological variables showed a positive correlation to storage time and temperature, and as storage time and temperature increased, the olfactory acceptability of oysters decreased. However, the $\mathrm{pH}$ of oyster homogenate did not show any significant decrease in this study. The authors suggest oyster storage temperatures at or below $10^{\circ} \mathrm{C}$ will be effective in controlling $V p$ growth, and it should be considered a CCP in HACCP plans used by the oyster industry. In addition, texture indicators showed an increase and then decrease in toughness of the oysters as storage temperature and time increased.

The result of this study should assist risk managers and seafood industry management in developing guidelines for oyster storage prior to their consumption. These findings should assist regulatory officials and the food industry in their review of policies on the handling of oysters. Also, the results of this research could assist risk assessors and the seafood industry in designing interventions to control the risk of vibrios to human health.

The authors suggest further research on glycogen levels and other physiological factors that may shed light on the role of microbial growth parameters in stored shellstock oysters. Also beyond the scope of this study was the enzymatic and protein chemistry of shellstock oysters under different storage conditions.

\section{ACKNOWLEDGMENTS}

This study was supported by the United States Department of Agriculture, National Research Initiative Grant \# 2006-35201-16644. The authors would also like to thank panelists who participated in the sensory evaluation study. The authors are grateful to students of the Food Microbiology and Safety Laboratory, Chanelle White, Drs. P. Chigbu, C. Brooks, K. Yoon, and L. DaSilva for their technical assistance and helpful suggestions.

\section{REFERENCES}

1. National Marine Fisheries Service. Status of the Eastern Oyster, Crassostrea virginica. (2007). Available from: http://www.nmfs.noaa.gov/pr/pdfs/ statusreviews/easternoyster.pdf

2. National Marine Fisheries Service. Status of the Eastern Oyster, Crassostrea virginica. (2012). Available from: http://www.st.nmfs.noaa.gov/st1/commercial/ landings/annual_landings.html

3. Chen L. Sensory and Chemical Characteristics of Eastern Oysters (Crassostrea virginica). Master's thesis (2011). Available from: 
http://scholar.lib.vt.edu/theses/available/etd-07012011-173454/unrestricted/ Chen_Luman_T_2011_copyright.pdf

4. Lorca AT, Pierson DM, Flick GJ, Hackney RC. Levels of V. vulnificus and organoleptic quality of raw shellstock oysters (Crassostrea virginica) maintained at different storage temperatures. J Food Prot (2001) 64:1716-21.

5. Parveen S, Hettiarachchi KA, Bowers JC, Nordstrom JL, Tamplin ML, McKay $\mathrm{R}$, et al. Seasonal distribution of total and pathogenic Vibrio parahaemolyticus in Chesapeake Bay oysters and waters. Int J Food Microbiol (2008) 128:354-61. doi:10.1016/j.ijfoodmicro.2008.09.019

6. Johnson CN, Flowers AR, Noriega NF, Zimmerman AM, Bowers JC, DePaola $\mathrm{A}$, et al. Relationships between environmental factors and pathogenic vibrios in the Northern Gulf of Mexico. Appl Environ Microbiol (2010) 76:7076-84. doi:10.1128/AEM.00697-10

7. Joseph SW, Colwell RR, Kaper BJ. Vibrio parahaemolyticus and related halophilic vibrios. Crit Rev Microbiol (1983) 10:77-123. doi:10.3109/ 10408418209113506

8. Jay JM. Foodborne gastroenteritis caused by Vibrio, Yersinia, and Campylobacter species. In: Heldman DR, editor. Modern Food Microbiology. Gaithersburg, MD: Aspen Publisher (2000). p. 549-68.

9. Centers for Disease Control and Prevention. Preliminary FoodNet data on the incidence of infection with 596 pathogens transmitted commonly through food - 10 states, United States, 2009. MMWR Morb Mortal Wkly Rep (2009) 59:418-22.

10. Food Safety News. Vibrio Outbreak in Washington State, Oysters Recalled. (2011). Available from: http://www.foodsafetynews.com/2011/09/vibrio outbreakinwashington-state-oysters-recalled/

11. Parveen S, Dasilva L, DePaola A, Bowers J, White C, Munasinghe KA, et al. Development and validation of a predictive model for the growth of $V p$ in postharvest shellstock oysters. Int J Food Microbiol (2013) 161:1-6. doi:10.1016/j. ijfoodmicro.2012.11.010

12. National Shellfish Sanitation Program. National shellfish sanitation program guide for the control of molluscan shellfish model ordinance Chapters VIII, IX, XI, XIII, XIV Section IV. Guidance Documents New Chapter - Time and Temperature Controls. (2012). p. 1-12. Available from: http://www.fda.gov/downloads/Food/GuidanceRegulation/ FederalStateFoodPrograms/UCM350344.pdf

13. United States Food and Drug Administration. Quantitative Risk Assessment on the Public Health Impact of Pathogenic Vp in Raw Oysters. Silver Spring, MD: Center for Food Safety and Applied Nutrition, FDA/US Department of Health and Human Services (2005).

14. Hunter AC, Linden BA. An investigation of oyster spoilage. Am Food J (1923) 18:538-40.

15. Cook WD, Ruple DA. Indicator bacteria and Vibrionaceae multiplication in post-harvest shellstock oysters. J Food Prot (1989) 52:343-9.

16. Bourne M. Food Texture and Viscosity: Concept and Measurement. New York, NY: Academic Press (2002).

17. Aussanasuwannakul A, Kenney PB, Brannan RG, Slider SD, Salem M, Yao J. Relating instrumental texture, determined by variable-blade and Allo-Kramer shear attachments to sensory analysis of rainbow trout, Oncorhynchus mykiss fillets. J Food Sci (2010) 75:S365-74. doi:10.1111/j.1750-3841.2010.01770.x

18. DePaola A, Kaysner CA. Vibrio. Bacteriological Analytical Manual Online. Washington, DC: U.S. Food and Drug Administration (2004). Available from: http:// www.fda.gov/food/foodscienceresearch/laboratorymethods/ucm2006949.htm

19. Nordstrom JL, Michael CL, Blackstone GM, Murray SL, DePaola A. Development of a multiplex real-time PCR assay with an internal amplification control for the detection of total and pathogenic Vibrio parahaemolyticus bacteria in oysters. Appl Environ Microbiol (2007) 73:5840-7. doi:10.1128/AEM.00460-07

20. Lawless HT, Heymann H. Sensory Evaluation of Food: Principles and Practices. Gaithersburg, MD: Aspen Publishers (1998).

21. Hood MA, Ness GE, Rodrick GE, Blake NJ. Effect of storage on microbial loads of two commercially important shellfish species, Crassostrea virginica and Mercenaria campechiensis. Appl Environ Microbiol (1983) 45:1221-8.

22. Cao R, Xue C, Liu Q, Xue Y. Microbiological, chemical, and sensory assessment of Pacific oysters (Crassostrea gigas) stored at different temperatures. Czech J Food Sci (2009) 27:102-8.

23. Dobraszcyk BJ, Vincent JF. Measurement of mechanical properties of food materials in relation to texture: the materials approach. In: Rosenthal AJ, editor. Food Texture: Measurement Perception. Gaithersburg, MD: Aspen Publishers (1999). p. 99-151.

24. Lee YS, Owens CM, Meullenet JF. On the quality of commercial boneless skinless broiler breast meat. J Food Sci (2008) 73:S253-61. doi:10.1111/j.1750-3841. 2008.00796.x

25. Ashie IN, Simpson BK. Effects of pressurization and refrigerated storage on microstructure of fish muscle tissue. J Muscle Foods (1998) 9:193-9. doi:10. 1111/j.1745-4573.1998.tb00654.x

26. Guyton AC, Hall JE. Text Book of Medical Physiology. 9th ed. PhiladelphiaLondon-Toronto-Montreal-Sydney-Tokyo: W.B. Saunders Company, A Division of Harcourt Brace Company (1996).

Conflict of Interest Statement: The authors declare that the research was conducted in the absence of any commercial or financial relationships that could be construed as a potential conflict of interest.

Received: 19 February 2014; paper pending published: 25 March 2014; accepted: 01 May 2014; published online: 16 May 2014.

Citation: Mudoh MF, Parveen S, Schwarz J, Rippen T and Chaudhuri A (2014) The effects of storage temperature on the growth of Vibrio parahaemolyticus and organoleptic properties in oysters. Front. Public Health 2:45. doi: 10.3389/fpubh.2014.00045

This article was submitted to Environmental Health, a section of the journal Frontiers in Public Health.

Copyright $\odot 2014$ Mudoh, Parveen, Schwarz, Rippen and Chaudhuri. This is an openaccess article distributed under the terms of the Creative Commons Attribution License (CC BY). The use, distribution or reproduction in other forums is permitted, provided the original author(s) or licensor are credited and that the original publication in this journal is cited, in accordance with accepted academic practice. No use, distribution or reproduction is permitted which does not comply with these terms. 